\title{
Genetic variability of Begonia longifolia Blume from Indonesia based on Nuclear DNA internal transcribed spacer (ITS) sequence data
}

\author{
WAHYU DEWI ASTUTI NINGRUM ${ }^{1}$, MUHAMMAD BIMA ATMAJA ${ }^{2}$, BUDI SETIADI DARYONO ${ }^{3, \bullet}$, \\ PURNOMO $^{4}$ \\ ${ }^{1}$ Laboratory of Plant Systematics, Faculty of Biology, Universitas Gadjah Mada. Jl. Teknika Selatan, Sekip Utara, Sleman 55281, Yogyakarta, Indonesia \\ ${ }^{2}$ Research Center for Plant Conservation and Botanic Gardens, Bali Botanic Gardens, Indonesian Institute of Science. Candikuning, Baturiti, Tabanan \\ 82191, Bali, Indonesia \\ ${ }^{3}$ Laboratory of Genetics and Breeding, Faculty of Biology, Universitas Gadjah Mada. Jl. Teknika Selatan, Sekip Utara, Sleman 55281, Yogyakarta, \\ Indonesia. Tel.: +62-274-580839, `email: bs_daryono@mail.ugm.ac.id \\ ${ }^{4}$ Laboratory of Plant Systematics, Faculty of Biology, Universitas Gadjah Mada. Jl. Teknika Selatan, Sekip Utara, Sleman 55281, Yogyakarta, Indonesia
}

Manuscript received: 14 September 2020. Revision accepted: 25 November 2020.

\begin{abstract}
Ningrum WDA, Atmaja MB, Daryono BS, Purnomo. 2020. Genetic variability of Begonia longifolia Blume from Indonesia based on Nuclear DNA internal transcribed spacer (ITS) sequence data. Biodiversitas 21: 5778-5785. Begonia longifolia Blume is a member of the Begoniaceae family which has the widest distribution in Asia including Indonesia. Diversity studies on B.longifolia from Indonesia were mainly based on morphological characters. The genetic diversity analysis of this pantropical species in Indonesia has never been reported yet. This research aimed to study genetic variability of $B$. longifolia in Indonesia based on nuclear DNA internal transcribed spacer (ITS) sequence data. Twelve living specimens were from Sumatra (Lampung), Java (Sukabumi, Purwokerto), Bali (Buleleng, Gianyar, Jembrana, Tabanan), and Lombok. The 831-839 length sequence was aligned using Mesquite software. Reconstruction of the phylogenetic tree was done by MEGA7 software using Neighbor-Joining method with Kimura-2-Parameter. The 827 fixed sites showed a genetic distance ranged from 0 to $1.6 \%$. Among the 827 sites compared, 802 sites were invariable, 19 sites were variable (11 singleton variable sites and 8 parsimony informative sites) and 6 sites were gaps. The phylogenetic tree showed 1 clade and 6 sub-clades. Specimens from Sumatra and Java formed a single sub-clade, separate with five sub-clades from Bali. Specimen from Lombok belong to one of the sub-clades of the Bali specimens. All specimens can be divided into 2 groups: Sumatra-Java and Bali-Lombok group.
\end{abstract}

Keywords: Begonia longifolia, intraspecific, molecular, nr DNA ITS, phylogenetic

\section{INTRODUCTION}

Begonia L. is one of the largest genera of Angiosperms, comprising around 1991 species and divided into 70 sections (Hughes et al. 2020). This pantropical genus can be used as a model to investigate the processes responsible for plant diversification to genera in other families (Moonlight et al. 2018). Begonia longifolia Blume is one of the members of Begonia, which has a widespread distribution. It is found in tropical regions including Malesia, Indo-China, Indian subcontinent to East Asia and China in warm climates (Govaerts and Sands 2018). The distribution of B. longifolia in Indonesia includes Sumatra, Java, Lesser Sunda Islands, and Sulawesi (Girmansyah 2008).

Plants show intraspecific variations in their development based on their adaptation to environmental changes (May et al. 2017). Adaptation may produce genetic differences between populations, which can cause different phenotypes (Schradin 2013). In addition, ecological and geographical factors also affect plant species' genetic diversity (Barros et al. 2018). Indonesia's diverse geographical conditions may lead to genetic variations in B. longifolia.
B. longifolia can be recognized with morphological characteristics, i.e.: perennial herb, no rhizome; stems erect, long internode, swollen node; leaves many, oblong, entire or toothed margin, glabrous; male flowers have four tepals, female flowers have six tepals; fruits have a thick and uniform size of wings (Girmansyah 2009). Morphological character plays a major role in the introduction of intraspecific variation. However, only a few characters are different from one another (Alcantara-Ayala et al. 2020). Morphological characters are strongly influenced by environmental factors and stages of plant development (Zhang et al. 2015). Therefore, study variation in intraspecific taxa requires a combination of several characters. Molecular characters can be used to reveal genetic variation and phylogenetic relationships because they are more varied (Nazar and Mahmood 2011; Tnah et al. 2016).

Internal Transcribed Spacer (ITS) region is located in the nuclear ribosomal DNA (nrDNA) gene complex of all eukaryotic cells. Nuclear rDNA consists of ITS 1, located between $18 \mathrm{~S}$ and $5.8 \mathrm{~S}$, and ITS 2, located between $5.8 \mathrm{~S}$ and 26S (Edger et al. 2014). This region is widely used for studies at the intraspecific level because it showed high variability within some species, such as Passiflora (Mäder et al. 2010), Withania somnifera (Mir et al. 2010) and 
Dioscorea alata (Purnomo et al. 2017). In Begonia, ITS sequences showed significant intra and interspecific differences (96\%-100\%) in B. biflora, B. guangxiensis, B. zhengyiana, B. cylindrical, B. megalophyllaria, and $B$. parvula (Jiao and Shui 2013). Studies on genetic variability in B.longifolia based on nrDNA ITS sequence has never been reported yet,, so this study is needed to be done. This research, therefore, aims to study the genetic variability of $B$. longifolia in Indonesia based on the nrDNA ITS sequence.

\section{MATERIALS AND METHODS}

\section{Plant materials}

Twelve living specimens of Begonia longifolia were used in the research. They were gathered from Sumatra (Lampung), Java (Sukabumi and Purwokerto), Bali (Buleleng, Gianyar, Jembrana, and Tabanan), and Lombok (Figure 1). The specimens were cultivated in two Botanic Gardens managed by the Indonesian Institute of Sciences: Bogor Botanic Gardens and Bali Botanic Gardens (Table 1).

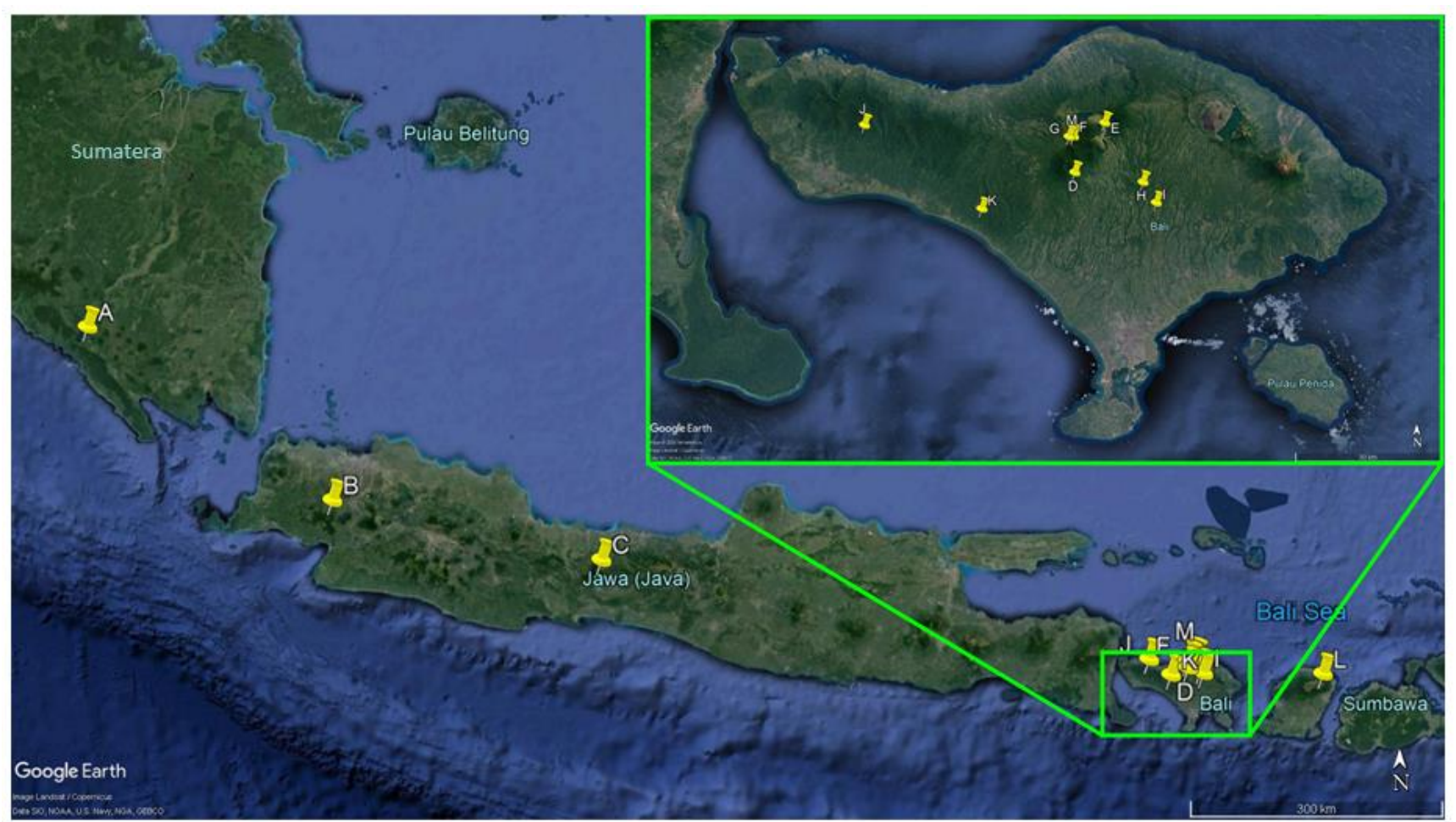

Figure 1. Maps of source of B.longifolia specimens: A. Lampung, B. Sukabumi, C. Purwokerto, D. Tabanan 1, E. Tabanan 2, F. Buleleng 1, G. Buleleng 2, H. Gianyar 1, I. Gianyar 2, J. Jembrana 1, K. Jembrana 2, L. Lombok, M. B.multangula (outgroup)

Table 1. Specimens and origins of B.longifolia used in this study

\begin{tabular}{lllll}
\hline No. Code & $\begin{array}{l}\text { Accession } \\
\text { number }\end{array}$ & Origin & Collection \\
\hline A & Lampung & B2017080056 Lumbok Seminung Protected Forest area, Liwa, West Lampung, Lampung & Bogor BG \\
B & Sukabumi & B2010036 & Halimun Mountain National Park, Cikaniki, Kabandungan, Sukabumi, West Java & Bogor BG \\
C & Purwokerto & E2004076 & Slamet Mountain Protected Forest area, sub-district Baturraden, Purwokerto, Central Java Bali BG & Bali BG \\
D & Tabanan 1 & E2006063 & Batukaru, Nature Conservation Area, Tabanan, Bali & Bali BG \\
E & Tabanan 2 & E20060631 & Candikuning village, sub-district Baturiti, Tabanan, Bali & Bali BG \\
F & Buleleng 1 & E20090981 & Sengayang Mountain, Batukaru Nature conservation area, subdistrict Banjar, Buleleng, Bali \\
G & Buleleng 2 & E20091052 & Batukaru, Nature Conservation Area, Gesing village, sub district Banjar, Buleleng, Bali & Bali BG \\
H & Gianyar 1 & E20100830 & Banjar Selat, Buahan village, sub-district Payangan, Gianyar, Bali & Bali BG \\
I & Gianyar 2 & E20100845 & Banjar Singa Perang, Buahan Kaja village, sub-district Payangan, Gianyar, Bali & Bali BG \\
J & Jembrana 1 & E20110934 & Mesehe Hill, Jembrana, Bali & Bali BG \\
K & Jembrana 2 & E2015060340 Tukad Yeh Leh, Pengeragoan Dangin Tukad village, subdistrict Pekutatan, Jembrana, Bali & Bali BG \\
L & Lombok & E2012120006 Rinjani Mountain National Park, East Lombok, West Nusa Tenggara & Bali BG \\
M & B.multangula & E200909104 & Sengayang Mountain, Batukaru Nature Conservation Area, subdistrict Banjar, Buleleng, Bali & Bali BG \\
\multicolumn{7}{c}{ (outgroup) } & & & &
\end{tabular}


The limitation of this study was the absence of the specimen from Sulawesi that was caused by the lack of specimen from Sulawesi in the Botanic Gardens. Begonia multangula Blume was chosen as an outgroup since this species is closely related and is placed in the same section with B. longifolia, both are in section Sphenanthera (Hassk.) Warb. (Hughes and Girmansyah 2011). The specimen of $B$. multangula was a collection of the Bali Botanic Gardens-Indonesian Institute of Science, originated from Buleleng, Bali.

DNA extraction and Polymerase Chain Reaction (PCR)

Total genomic DNA was isolated from $100 \mathrm{mg}$ freeze B. longifolia and B. multangula leaves by using Phytopure. DNA quantity and purity were estimated by using a nanodrop spectrophotometer (Maestrogen). Template DNA was adjusted to $20 \mathrm{ng} \mu \mathrm{L}^{-1}$

Amplification was performed in a PCR Thermal Cycler (Biorad). Two sets of primers used in this research were ITS-u1 as forward (5'-GGAAGKARAAGTCGTAACAAGG3') and ITS-u4 as reverse (5'-RGTTTCTTTTCCTCCGCTTA3') (Cheng et al. 2016). PCR was carried out in $25 \mu \mathrm{L}$ reactions containing: $12.5 \mu \mathrm{L}$ Bioline-My Taq HS Red mix reagent, $1 \mu \mathrm{L}$ forward primer $10 \mu \mathrm{M} \mu \mathrm{L}^{-1}, 1 \mu \mathrm{l}$ reverse primer $10 \mu \mathrm{M} \mu \mathrm{L}^{-1}, 1 \mu \mathrm{l}$ genomic DNA $20 \mathrm{ng} \mu \mathrm{L}^{-1}$ and 9.5 $\mu \mathrm{L}$ ddH2O. Amplification was performed under the following condition: One cycle pre-denaturation $\left(94^{\circ} \mathrm{C}\right.$, for 4 minutes), followed by 30 amplification cycles (denaturation $94^{\circ} \mathrm{C}$ for 1 minute, annealing $52^{\circ} \mathrm{C}$ for 1 minute, elongation $72^{\circ} \mathrm{C}$ for 1 minute), and extended elongation for 10 minutes in $72^{\circ} \mathrm{C}$. The PCR products were then electrophoresed for 55 minutes in 50 volts on $2 \%$ agarose gel in $1 x$ TBE Buffer containing 4\% Flourosafe DNA Stain. The agarose gel was then visualized in GelDoc. The accession with the correct band at the size of 700-900 bp (Cheng et al. 2016) was then sequenced. PCR products were sent by courier to PT. Genetics Science to be analyzed at 1st BASE DNA Sequencing Service Malaysia. Sequencing is carried out by using the Sanger sequencing method.

\section{Data analysis}

Sequences were fixed and edited by using Genestudio software (version 2.2.0.0) to make a contig. Sequences were then verified the similarity with the database of NCBI Genbank by BLAST. The alignment was performed using OPAL in Mesquite software (version 3.31). Genetic distances between sequences were estimated using Multiple pairwise in MEGA7 software (version 7.0.26). Reconstruction of the phylogenetic tree was done by MEGA7 software using the Neighbor-Joining method with the Kimura-2-parameter substitution model at 1000 bootstrap. Twelve specimens of $B$. longifolia and one specimen of $B$. multangula sequences were deposited in NCBI GenBank with accession number MN453422-MN453434.

\section{RESULTS AND DISCUSSION}

\section{Amplification of nrDNA ITS region}

Twelve specimens of B. longifolia and one specimen of B. multangula as an outgroup were successfully amplified by the primers. The primers used in the PCR amplified regions $18 \mathrm{~S}$, ITS1, 5.8S, and ITS2, 26S, with total lengths of 700-900 bp (Cheng et al. 2016). In B. longifolia, the size obtained in electrophoresis was 800 bp (Figure 2).

The result of BLAST analysis indicated that all specimens of $B$. longifolia had a high similarity to $B$. aptera (Genbank accession number: AJ491196.1), with the identity value ranged from 97.34-97.84\%. B. multangula had a high similarity to Begonia sp. (Genbank accession number: AF485098.1) with the identity value 95,35\% (Table 2). B. aptera belongs to section Sphenanthera, same with B. longifolia and B.multangula (Girmansyah et al. 2009; Thomas et al. 2011).

The total nucleotides of all specimens for BLAST analysis ranged from $822-824 \mathrm{bp}$. There were only two accessions of ITS sequence of B.longifolia deposited in NCBI with less size [accession number: AF485105.1 (738 bp) and AY753723.1 (681 bp)]. At the same time, there was no ITS sequence of B.multangula in NCBI. ITS sequence of B.multangula in this study was the first ITS sequence of B.multangula deposited in NCBI. A very limited sequence of nrDNA ITS region of $B$. longifolia and B.multangula in Genbank might be the reason for the misidentification in this study.

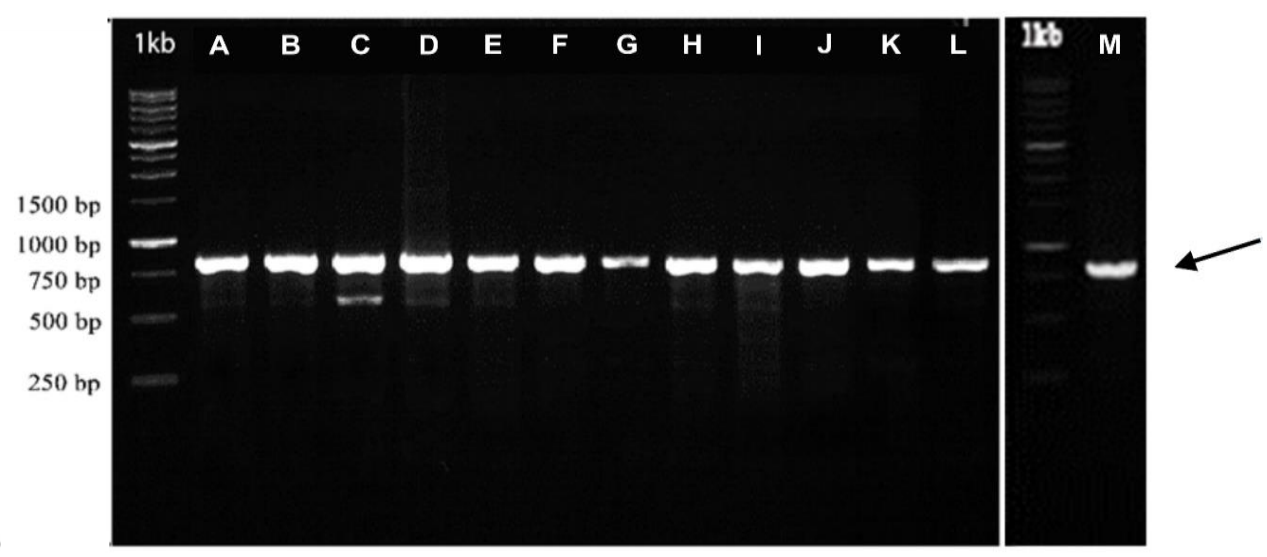

Figure 2. Electrophoregram of nrDNA ITS region of Begonia longifolia (arrow). A. Lampung; B. Sukabumi; C. Purwokerto; D. Tabanan 1; E. Tabanan 2; F. Buleleng 1; G. Buleleng 2; H. Gianyar 1; I. Gianyar 2; J. Jembrana 1; K. Jembrana 2; L. Lombok; M. B. multangula 
Table 2. BLAST analysis of nrDNA ITS sequence of B. longifolia

\begin{tabular}{lccccc}
\hline \multicolumn{1}{c}{ Specimens code } & $\begin{array}{c}\text { Accession number in } \\
\text { Genbank }\end{array}$ & Most similar species & $\begin{array}{c}\text { Accession number in } \\
\text { Genbank }\end{array}$ & $\begin{array}{c}\text { Query } \\
\text { cover (\%) }\end{array}$ & \begin{tabular}{c} 
Identity (\%) \\
\hline Lampung
\end{tabular} \\
MN453422 & B. aptera & AJ491196.1 & 95 & 97.84 \\
Sukabumi & MN453423 & B. aptera & AJ491196.1 & 95 & 97.46 \\
Purwokerto & MN453424 & B. aptera & AJ491196.1 & 95 & 97.84 \\
Tabanan 1 & MN453425 & B. aptera & AJ491196.1 & 95 & 97.71 \\
Tabanan 2 & MN453426 & B. aptera & AJ491196.1 & 95 & 97.71 \\
Buleleng 1 & MN453427 & B. aptera & AJ491196.1 & 95 & 97.71 \\
Buleleng 2 & MN453428 & B. aptera & AJ491196.1 & 95 & 97.59 \\
Gianyar 1 & MN453429 & B. aptera & AJ491196.1 & 95 & 97.84 \\
Gianyar 2 & MN453430 & B. aptera & AJ491196.1 & 95 & 97.59 \\
Jembrana 1 & MN453431 & B. aptera & AJ491196.1 & 95 & 97.71 \\
Jembrana 2 & MN453432 & B. aptera & AJ491196.1 & 95 & 97.84 \\
Lombok & MN453433 & B. aptera & AJ491196.1 & 95 & 97.34 \\
B.multangula & MN453434 & Begonia sp. & AF485098.1 & 96 & 95,35 \\
(outgroup) & & & & & \\
\hline
\end{tabular}

Analysis of sequence data using nrDNA ITS region has been used for identification on species level (Forrest and Hollingsworth 2003; Forrest et al. 2005; Jiao and Shui 2013). A non-coding plastid DNA ( $n d h A$ intron, $n d h F$ rpl32 and rpl32-trnL spacers) sequence also provided strong evidence for the polyphyly of section Sphenanthera (Thomas et al. 2011). The combination of sequences from the nrDNA and trnL intron has also been used to generate phylogenetic analysis within Begoniaceae (Plana et al. 2004).

Begonia aptera is a sister taxa of B. longifolia based on molecular data on chloroplasts gene. Analysis of the split time of the two species occurred relatively new (Thomas et al. 2011). B. aptera $(=B$. cristata $)$ is one of the species complexes of $B$. longifolia. Morphologically, these two species look similar with slight differences (Table 3).

\section{Genetic variation}

The total alignment provided an 827 bp in the matrix. The composition of nucleotides of B.longifolia ranged from 822-824 (Table 4). Among 827 sites, 802 sites were invariable (monomorphic), 19 sites were variable (polymorphic), six sites were gaps. Sites with gaps were on sites 12, 13, 43, 789, 790, and 795. Among 19 variable sites, 11 were singleton variable sites, and eight sites were parsimony informative sites. Sites with single variation were found in nucleotides $2,10,16,18,88,192,236,425$,
748, 824 and 825. Parsimony sites were found in nucleotides $3,4,7,8,9,11,120$, and 471 (Table 5). The variations in the nucleotide bases that occur on these sites were due to a nucleotide base substitution in the form of transition and transversion, while the presence of gaps caused the different composition of nucleotides due to the presence of insertion and deletion (Mir et al. 2010).

The genetic distance of all specimens of $B$. longifolia ranged from 0-1.6\%, with a mean genetic distance of 0.68 $\%$ (Table 6). According to Jiao and Shui (2013), the ITS fragment has the greatest intraspecies variability among rbcL, matK and trnH-psbA sequences, with a mean of intraspecies distance $0.39 \pm 0.12 \%$ in 136 specimens representing 26 species of Begonia. In line with its result, our result showed high variation among twelve specimens B. longifolia. Genetic distance is defined as a measure of evolutionary divergence between homologous gene sequences from the same ancestor. The calculation of genetic distance is where the difference between the two genes is comparable to the time since they have the same ancestor (Beaumont et al. 1998). The genetic distance represents the difference between individu during evolutionary process. According to Qin et al. (2017), the threshold for ITS2 genetic distance in intraspecies of seed plants is $3.76 \%$. Based on the value, all specimens were classified as intraspecies.

Table 3. The morphological difference between Begonia longifolia and B. aptera

\begin{tabular}{|c|c|c|c|}
\hline \multirow{2}{*}{ Character } & \multicolumn{2}{|r|}{ Species } & \multirow{2}{*}{ References } \\
\hline & B. longifolia & B. aptera & \\
\hline Leaf shape & Lanceolate or broadly elliptic & Broadly elliptic & \\
\hline Leaf margin & $\begin{array}{l}\text { Shallowly single toothed to } \\
\text { almost entire }\end{array}$ & $\begin{array}{l}\text { Remotely, short and somewhat irregularly } \\
\text { bidentate, smaller teeth serrate }\end{array}$ & Tebbit (2003) \\
\hline Number of flowers in & Many, more than 10 & Few, less than 10 & \\
\hline $\begin{array}{l}\text { each intlorescence } \\
\text { Fruit shape } \\
\text { Fruit surface } \\
\text { Stigma attachment }\end{array}$ & $\begin{array}{l}\text { Round } \\
\text { Rough small bumps } \\
\text { Strongly attached }\end{array}$ & $\begin{array}{l}\text { Slightly square } \\
\text { Smooth } \\
\text { Easily fell off }\end{array}$ & $\begin{array}{l}\text { Wiriadinata and } \\
\text { Girmansyah (2011) }\end{array}$ \\
\hline
\end{tabular}


Table 4. Nucleotide composition of ITS sequence data in Begonia longifolia

\begin{tabular}{|c|c|c|c|c|c|c|}
\hline \multirow{2}{*}{ Specimens code } & \multirow{2}{*}{ Total nucleotide } & \multirow{2}{*}{$\begin{array}{c}\text { Total aligned } \\
\text { nucleotide }\end{array}$} & \multicolumn{4}{|c|}{ Nucleotide composition } \\
\hline & & & $\mathbf{T}$ & $\mathbf{C}$ & $\mathbf{A}$ & $\mathbf{G}$ \\
\hline Lampung & 826 & 824 & $177(21 \%)$ & $224(27 \%)$ & $188(23 \%)$ & $235(29 \%)$ \\
\hline Sukabumi & 832 & 822 & $181(22 \%)$ & $222(27 \%)$ & $184(22 \%)$ & $235(29 \%)$ \\
\hline Purwokerto & 835 & 823 & $178(22 \%)$ & $223(27 \%)$ & $186(23 \%)$ & $236(29 \%)$ \\
\hline Tabanan 1 & 832 & 823 & $179(22 \%)$ & $223(27 \%)$ & $186(23 \%)$ & $235(29 \%)$ \\
\hline Tabanan 2 & 828 & 821 & $178(22 \%)$ & $223(27 \%)$ & $185(23 \%)$ & $235(29 \%)$ \\
\hline Buleleng 1 & 835 & 822 & $179(22 \%)$ & $223(27 \%)$ & $186(23 \%)$ & $234(28 \%)$ \\
\hline Buleleng 2 & 839 & 822 & $179(22 \%)$ & $223(27 \%)$ & $185(23 \%)$ & $235(29 \%)$ \\
\hline Gianyar 1 & 836 & 822 & $178(22 \%)$ & $223(27 \%)$ & $184(22 \%)$ & $237(29 \%)$ \\
\hline Gianyar 2 & 831 & 824 & $179(22 \%)$ & $223(27 \%)$ & $187(23 \%)$ & $235(29 \%)$ \\
\hline Jembrana 1 & 833 & 822 & $178(22 \%)$ & $223(27 \%)$ & $186(23 \%)$ & $235(29 \%)$ \\
\hline Jembrana 2 & 832 & 822 & $178(22 \%)$ & $223(27 \%)$ & $186(23 \%)$ & $235(29 \%)$ \\
\hline Lombok & 837 & 824 & $181(22 \%)$ & $222(27 \%)$ & $186(23 \%)$ & $235(29 \%)$ \\
\hline $\begin{array}{l}\text { B.multangula } \\
\text { (outgroup) }\end{array}$ & 835 & 823 & $178(22 \%)$ & $227(28 \%)$ & $182(22 \%)$ & $236(28 \%)$ \\
\hline
\end{tabular}

Table 5. Variation in B. longifolia sequences

\begin{tabular}{|c|c|}
\hline $\begin{array}{l}\text { Specimens } \\
\text { code }\end{array}$ & $\begin{array}{c}\text { Base nucleotide position } \\
11244777788 \\
1111114829327489922 \\
2347890123683802651890545\end{array}$ \\
\hline Lampung & GGAGAAAAAAGC-CCCGCGCT--GA \\
\hline Sukabumi & TTG.G.G.-..-T..СT.T--- . \\
\hline Purwokerto & T..G..G..-T....-- \\
\hline Tabanan 1 & TTG.G.......T..A.--_. \\
\hline Tabanan 2 & T.G.G...-..T..A.-- . \\
\hline Buleleng 1 & TTG.G.....-.T..A.---. \\
\hline Buleleng 2 & TTG.G..G--..A.T..A.--- . \\
\hline Gianyar 1 & T.G.GG....-.T...--AG \\
\hline Gianyar 2 & T.GAGG.G. .AT-.T. .A.--C. \\
\hline Jembrana 1 & T.G.G.....-T..A.--- . \\
\hline Jembrana 2 & T.G.......T...-- \\
\hline Lombok & T.GAGG. . . . .TT..A. T- . \\
\hline
\end{tabular}

Variations within organisms can be used to study evolution (Alcántara-Ayala et al. 2020). The broad distribution of B.longifolia is caused by its wide ecological tolerance and greater chances of long-distance dispersal afforded by its baccate, and therefore presumably animaldispersed. The variation in B.longifolia was dominantly caused by population isolation (Tebbit 2003). Variations in population levels are congruent with macroevolution in the genus Begonia (Hughes and Hollingswort 2008).

\section{Reconstruction of the phylogenetic tree}

The phylogenetic tree is a diagram that shows the estimated evolutionary relationship among a group of species based on molecular characters (Philippe et al. 2011). Evolution is a gradual process of change from simple species to become more complex through the accumulation of genetic mutation from several generations (Dharmayanti 2011). The rate of evolution can be known from variations in gene sequences or DNA segments. The closeness relationship between samples is influenced by the length of the branches. Branch lengths are proportional to the genetic distances inferred from the analysis of a multiple alignments of homologous sequence (Philippe et al. 2011).

Table 6. Genetic distance (\%) among twelve specimens of B. longifolia

\begin{tabular}{|c|c|c|c|c|c|c|c|c|c|c|c|c|c|}
\hline No. & Specimens code & 1 & 2 & 3 & 4 & 5 & 6 & 7 & 8 & 9 & 10 & 11 & 12 \\
\hline 1. & Lampung & & & & & & & & & & & & \\
\hline 2. & Sukabumi & 1.1 & & & & & & & & & & & \\
\hline 3. & Purwokerto & 0.4 & 1.0 & & & & & & & & & & \\
\hline 4. & Tabanan 1 & 0.7 & 0.9 & 0.4 & & & & & & & & & \\
\hline 5. & Tabanan 2 & 1.1 & 1.2 & 0.7 & 0.4 & & & & & & & & \\
\hline 6. & Buleleng 1 & 0.7 & 0.9 & 0.4 & 0.0 & 0.4 & & & & & & & \\
\hline 7. & Buleleng 2 & 0.7 & 0.9 & 0.4 & 0.0 & 0.4 & 0.0 & & & & & & \\
\hline 8. & Gianyar 1 & 1.4 & 1.2 & 1.0 & 0.9 & 0.5 & 0.9 & 0.9 & & & & & \\
\hline 9. & Gianyar 2 & 1.2 & 1.6 & 0.9 & 0.7 & 0.6 & 0.7 & 0.7 & 1.1 & & & & \\
\hline 10. & Jembrana 1 & 1.1 & 1.2 & 0.7 & 0.4 & 0.0 & 0.4 & 0.4 & 0.5 & 0.6 & & & \\
\hline 11. & Jembrana 2 & 0.9 & 1.0 & 0.5 & 0.4 & 0.2 & 0.4 & 0.4 & 0.5 & 0.9 & 0.2 & & \\
\hline 12. & Lombok & 1.0 & 1.4 & 0.6 & 0.5 & 0.4 & 0.5 & 0.5 & 0.9 & 0.5 & 0.4 & 0.6 & \\
\hline
\end{tabular}




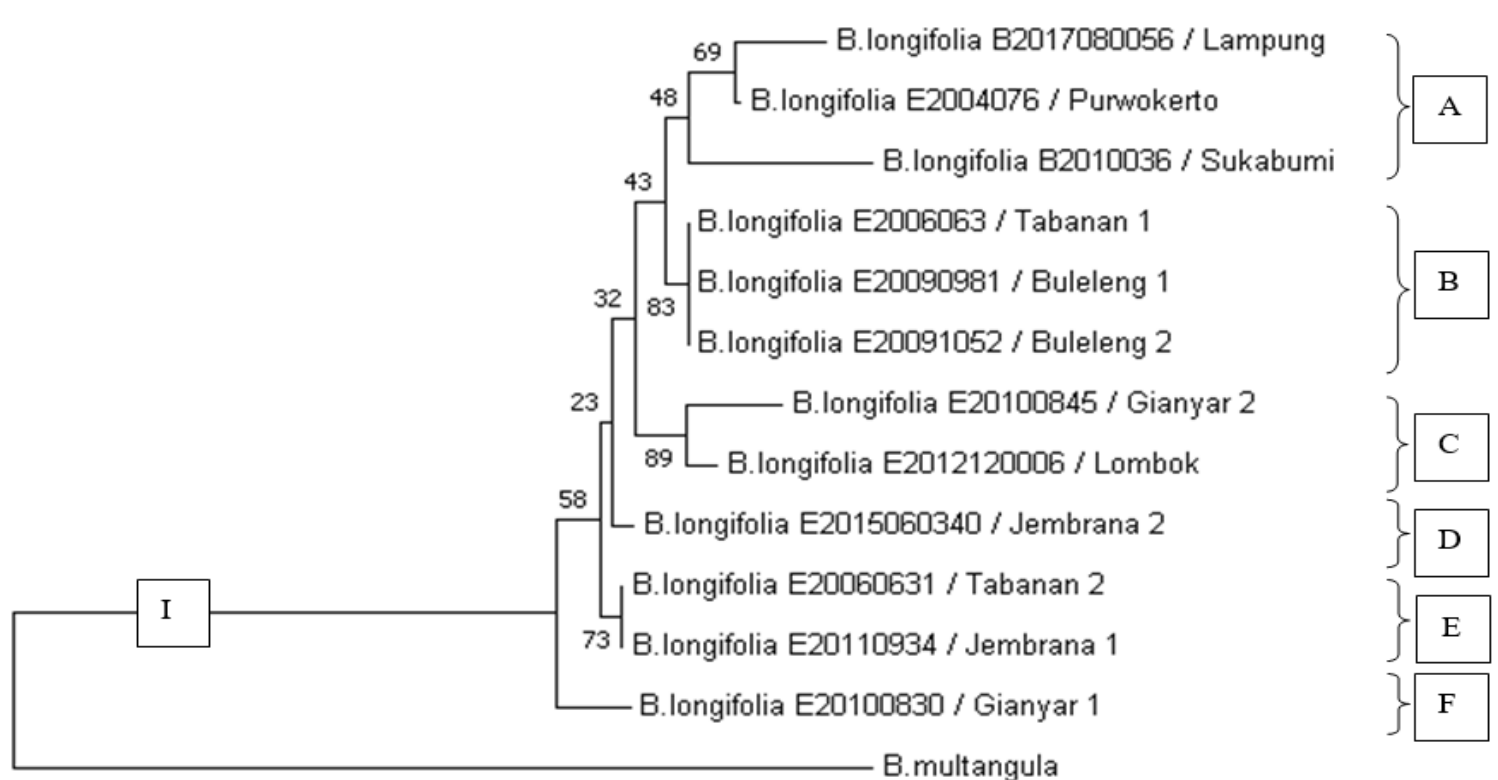

B. multangula

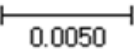

Figure 3. Phylogenetic tree of $B$. longifolia derived from Neighbor Joining method based on nrDNA ITS sequence data

Begonia multangula was succesfully separated among B. longifolia specimens. Phylogenetic trees formed only one main clade, clade I. Clade I consisted of 6 sub-clades, namely A, B, C, D, E, and F. Sub-clade A consisted of Lampung, Sukabumi, and Purwokerto specimens. In subclade A, the separation between branches was supported by a small bootstrap value of $48 \%$. Sub-clade B consisted of Tabanan 1, Buleleng 1, and Buleleng 2 specimens. In subclade $\mathrm{B}$, branches formed a straight line, which means the three specimens were identic in the ITS-rDNA sequence with genetic distance values of all three samples was 0.0. These branches were supported with a bootstrap value of $83 \%$. Sub-clade C consisted of Gianyar 2 and Lombok specimens. Sub-clade D consisted of Jembrana 2 specimens. Sub-clade E consisted of Tabanan 2 and Jembrana 1 specimens. In sub-clade E, branches formed a straight line, which means the two samples were identic in the ITS-rDNA sequence with a genetic distance value of 0.0. Sub-clade F consisted of Gianyar 1 specimens (Figure 3). The phylogenetic analysis based on nrDNA ITS sequence showed that twelve specimens of B. longifolia are monophyletic.

The grouping of $B$. longifolia based on molecular characters might indicate the geographical difference. A study in the population of $B$. luzhaiensis using EST-SSR marker and the chloroplast $t r n C-y c f 6$ intergenic spacer in China indicated that historical fragmentation and isolation by distance influenced the phylogeographic analysis (Tseng et al. 2019). Sub-clade A consisted of Lampung, Sukabumi, and Purwokerto specimens. Lampung is located in Sumatra, while Sukabumi and Purwokerto are located in Java. Based on its geographical area, Sumatra and Java are included on the Sunda shelf. During the Pleistocene glacial period, the rising and falling sea levels caused islands on the Sunda shelf to separate and fuse with each other. Sumatra and Java were previously fused but subsequently separated (Lohman et al. 2011). This Pleistocene glaciation influenced the pattern of genetic diversity of species (Ramirez-Barahona and Eguiarte 2013). Hence, specimens from Lampung, Sukabumi, and Purwokerto are placed in one sub-clade.

Sub-clade B consisted of Tabanan 1, Buleleng 1, and Buleleng 2 specimens. The three specimens have a meager genetic distance $(0,0)$. The zero value of genetic distance is due to the small sequence variations between specimens. Based on the origin of their habitat, all three specimens were from the Batukaru Nature Conservation area. Administratively, Batukaru Nature Conservation is located across the regencies of Buleleng, Tabanan, and Badung. According to Tsai et al. (2015), the similarity of these three specimens habitat tends to have low genetic diversity at the intraspecific level. It can be seen in the phylogenetic analysis of Phalaenopsis amabilis using ITS and trnH-psbA sequence divided most of the specimens of $P$. amabilis species complex based on the origin of the specimen.

Sub-clade C consisted of Gianyar 2 and Lombok specimens. According to Lohman et al. (2011), Bali is included in the Sunda Shelf while Lombok is included in the Wallacea region. A line separates the Sunda shelf and Wallacea between Borneo and Sulawesi (Celebes) and through the Lombok Strait between Bali and Lombok. Wallacean islands are generally regarded as oceanic islands because they have had no terrestrial connection to any surrounding land (Sulawesi is the exception). Consequently, their biota arose predominantly via dispersal and not vicariance. The distance between Bali and Lombok is near, while $B$. longifolia has a very wide distribution. The type of fruit and seed structure allows animals and 
wind to help its distribution (Tebbitt, 2003). These might be the factors that $B$. longifolia in Bali and Lombok are similar based on molecular characters.

Sub-clade D only consisted of Jembrana 2 specimen. Sub-clade E consisted of Tabanan 2 and Jembrana 1 specimens. Those two specimens also have a zero value of genetic distance. Sub-clade F only consisted of Gianyar 1 specimen. Specimen of sub-clade D, E, and F were not from the same area. B. longifolia is generally found in a wide range of habitats from primary rainforest to degraded scrub, on acidic to basic substrate, in full to half shade. Usually in moist soils, but not in seasonally waterlogged sites at altitudes 120-2000 m asl. (Tebbit 2003, Wiriadinata and Girmansyah 2011). A study in Caragana microphylla in Horqin Sandy Land, China, using inter simple sequence repeat (ISSR) markers, indicated a correlation between different environmental gradients and genetic variation. C. microphylla has high genetic diversity, and ecological gradients affected the genetic diversity of C. microphylla populations (Huang et al. 2016). The different habitats and environments might be the factor in the grouping of those specimens.

The grouping of the phylogenetic tree of $B$. longifolia specimens was influenced by geographical difference and habitat environment. Specimens from Sumatra and Java formed a single sub-clade, separate with five sub-clades from Bali. Specimen from Lombok belong to one of the sub-clades of the Bali specimens. Based on the grouping pattern, there was a trend that the specimens from Lampung, Sukabumi, and Purwokerto separated from the specimens from Bali and Lombok. Therefore, it can be divided into two groups, i.e. Sumatra-Java and BaliLombok group.

\section{ACKNOWLEDGEMENTS}

We thank Bogor Botanic Gardens and Bali Botanic Gardens-Indonesian Institute of Science for permitting us to do research and use the collection of Begonia longifolia. The authors also acknowledge the financial support for this research provided by Indonesia Endowment Fund for Education (LPDP), Ministry of Finance, the Republic of Indonesia for 2017-2019 granted to the first author.

\section{REFERENCES}

Alcántara-Ayala O, Oyama K, Ríos-Muñoz, Rivas G, Ramirez-Barahona S, Luna-Vega I. 2020. Morphological variation of leaf traits in the Ternstroemia lineata species complex (Ericales: Penthaphylacaceae) in response to geographic and climatic variation. PeerJ 8: e8307. DOI: 10.7717/peerj.8307.

Barros MJF, Diniz-Filho JAF, Freitas LB. 2018. Ecological drivers of plant genetic diversity at the southern edge of geographical distributions: Forestal vines in a temperate region. Genet Mol Biol 41 (1 (suppl)): 318-326. DOI: 10.1590/1678-4685-GMB-2017-0031.

Beaumont MA, Ibrahim KM, Boursot P, Bruford MW. 1998. Measuring genetic distance. In: Karp A, Isaac PG, Ingram DS. Molecular Tools for Screening Biodiversity. Chapman \& Hall, London.

Cheng T, Xu C, Lei L, Li C, Zhang Y, Zhou S. 2016. Barcoding the kingdom Plantae: new PCR primers for ITS regions of plants with improved universality and specificity. Mol Ecol Resour 16: 138-149. DOI: 10.1111/1755-0998.12438.

Dharmayanti NLPI. 2011. Molecular phylogenetics: taxonomic methods of organisms based on the history of evolution. Wartazoa 21 (1) : 110. [Indonesian]

Edger PP, Tang M, Bird KA, Mayfield DR, Conant G, Mummenhoff K, Koch MA, Pires JC. 2014. Secondary structure analyses of the nuclear rRNA internal transcribed spacers and assessment of its phylogenetic utility across the Brassicaceae (mustards). PLoS One 9 (7): 1-7. DOI:10.1371/journal.pone.0101341.

Forrest LL, Hollingsworth PM. 2003. A recircumscription of Begonia based on nuclear ribosomal sequences. Plant Syst Evol 241: 193-211. DOI: 10.1007/s00606-002-0033-y.

Forrest LL, Hughes M, Hollingsworth PM. 2005. A phylogeny of Begonia using nuclear ribosomal sequence data and morphological characters. Syst Bot 30 (3): 671-682. DOI: 10.1600/0363644054782297.

Girmansyah D. 2008. Diversity of wild Begonia (Begoniaceae) species in West Java. Berita Biologi 9 (2): 195-203. DOI: 10.14203/beritabiologi.v9i2.2028. [Indonesian]

Girmansyah D. 2009. A taxonomic study of Bali and Lombok Begonia (Begoniaceae). Reinwardtia 12 (5): 419-434. DOI: 10.14203/reinwardtia.v12i5.81.

Girmansyah D, Wiriadinata H, Thomas DC, Hoover WS. 2009. Two new species and one new subspecies of Begonia (Begoniaceae) from Southeast Sulawesi, Sulawesi, Indonesia. Reinwardtia 13 (1): 69-74. DOI: 10.14203/reinwardtia.v13i1.4.

Govaerts R, Sands MJS. 2018. World checklist of Begoniaceae. The Royal Botanic Gardens, Kew.

Huang W, Zhao X, Zhao X, Li Y, Lian J. 2016. Effects of environmental factors on genetic diversity of Caragana microphylla in Horqin Sandy Land, northeast China. Ecol Evol 6 (22): 8256-8266. DOI:10.1002/ece3.2549.

Hughes M., Hollingsworth PM, 2008. Population genetic divergence corresponds with species level biodiversity patterns in the large genus Begonia. Mol Ecol 17 (11): 2643-2651. DOI:10.1111/j.1365294X.2008.03788.xHughes M, Girmansyah D. 2011. A revision of Begonia sect. Sphenanthera (Hassk.) Warb. from Sumatra. Gard. Bull. Singapore 62 (2): 27-39.

Hughes M, Moonlight PW, Jara-Muñoz A, Tebbitt MC, Wilson HP, Pullan M. 2020. Begonia resource centre: online database. http://padme.rbge.org.uk/begonia/

Jiao LJ, Shui YM. 2013. Evaluating candidate DNA barcodes among Chinese Begonia (Begoniaceae) species. Plant Div Resour 35 (6): 715-724. DOI: $10.7677 /$ ynzwyj201313064

Lohman DJ, de Bruyn M, Page T, von Rintelen K, Hall R, Ng PKL, Shih H-T, Carvalho GR, von Rintelen T. 2011. Biogeography of the IndoAustralian archipelago. Annu Rev Ecol Evol Syst 42: 205-26. DOI:10.1146/annurev-ecolsys-102710-145001.

Mäder G, Zamberlan PM, Fagundes NJR, Magnus T, Salzano FM, Bonatto SL, Freitas LB. 2010. The use and limits of ITS data in the analysis of intraspecific variation in Passiflora L. (Passifloraceae). Genet Mol Biol 33 (1): 99-108 DOI: 10.1590/S141547572009005000101.

May R, Warner S, Wingler A. 2017. Classification of intra-specific variation in plant functional strategies reveals adaptation to climate. Ann Bot 119: 1343-1352. DOI: 10.1093/aob/mcx031.

Mir BA, Koul S, Kumar A, Kaul MK, Soodan AS, Raina SN. 2010. Intraspecific variation in the internal transcribed spacer (ITS) regions of rDNA in Withania somnifera (Linn.) Dunal. Indian J Biotechnol 9: 325-328.

Moonlight PW, Ardi WH, Padilla LA, Chung K-F, Fuller D, Girmansyah D, Hollands R, Jara-Muñoz A, Kiew R, Leong W-C, Liu Y, Mahardika A, Marasinghe LDK, O’Connor M, Peng C-I, Pérez AJ, Phutthai T, Pullan M, Rajbhandary S, Reynel C, Rubite RR, Sang J, Scherberich D, Shui Y-M, Tebbitt MC, Thomas DC, Wilson HP, Zaini NH, Hughes M. 2018. Dividing and conquering the fastestgrowing genus: towards a natural sectional classification of the megadiverse genus Begonia (Begoniaceae). Taxon 67 (2): 267-323. DOI: 10.12705/672.3.

Nazar N, Mahmood T. 2011. Morphological and molecular characterization of selected Artemisia species from Rawalakot, Azad Jammu and Kashmir. Acta Physiol Plant 33: 625-633. DOI: 10.1007/s11738-010-0545-3.

Philippe H, Brinkmann H, Lavrov DV, Littlewood DTJ, Manuel M, Wörheide G, Baurain D. 2011. Resolving difficult phylogenetic 
questions: why more sequences are not enough. PLoS Biol 9 (3): e1000602. DOI: $10.1371 /$ journal.pbio. 1000602 .

Plana V, Gascoigne A, Forrest LL, Harris D, Pennington RT. 2004 Pleistocene and pre-Pleistocene Begonia speciation in Africa. Mol

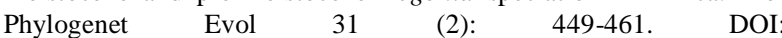
b10.1016/j.ympev.2003.08.023 .

Purnomo, Daryono BS, Shiwachi H. 2017. Phylogenetic relationship of Indonesian water yam (Dioscorea alata L.) cultivars based on DNA marker using ITS-rDNA analysis. J Agric Sci 9 (2): 154-161. DOI: $10.5539 /$ jas.v9n2p154.

Qin Y, Li M, Cao Y, Gao Y, Zhang W. 2017. Molecular thresholds of ITS2 and their implications for molecular evolution and species identification in seed plants. Sci Rep 7 (1): 17316 DOI:10.1038/s41598-017-17695-2.

Ramirez-Barahona S, Eguiarte LE. 2013. The role of glacial cycles in promoting genetic diversity in the Neotropics: the case of cloud forests during the Last Glacial Maximum. Ecol Evol 3 (3): 725-738.

Schradin C. 2013. Intraspecific variation in social organization by genetic variation, developmental plasticity, social flexibility or entirely extrinsic factors. Phil Trans R Soc B 368: 20120346. DOI: 10.1098/rstb.2012.0346.

Tebbitt MC. 2003. Taxonomy of Begonia longifolia Blume (Begoniaceae) and related species. Brittonia 55 (1): 19-29. DOI: 10.1663/0007-196X (2003)055[0019:TOBLBB]2.0.CO;2 .
Thomas DC, Hughes M, Phutthai T, Rajbhandary S, Rubite R, Ardi WH, Richardson JE. 2011. A non-coding plastid DNA phylogeny of Asian Begonia (Begoniaceae): evidence for morphological homoplasy and sectional polyphyly. Mol Phylogenet Evol 60: 428-444. DOI:10.1016/j.ympev.2011.05.006.

Tnah LH, Lee SL, Tan AL, Lee CT, Ng KKS, Ng CH. 2016. Intraspecific classification of Ficus deltoidea Jack subsp. deltoidea (Moraceae) in Peninsular Malaysia based on morphological and molecular variations. Biochem Syst Ecol 67: 119-128. DOI: 10.1016/j.bse.2016.06.001.

Tsai CC, Chou CH, Wang HV, Ko YZ, Chiang TY, Chiang YC. 2015 Biogeography of the Phalaenopsis amabilis species complex inferred from nuclear and plastid DNAs. BMC Plant Biol 15 (202): 1-16 DOI: 10.1186/s12870-015-0560-Z

Tseng YH, Huang HY, Xu WB, Yang HA, Peng CI, Liu Y, Chung KF. 2019. Phylogeography of Begonia luzhaiensis suggests both natural and anthropogenic causes for the marked population genetic structure. Bot Stud 60 (20): 1-19. DOI: 10.1186/s40529-019-0267-9.

Wiriadinata H, Girmansyah D. 2011. Begonia plant (Begoniaceae) in Uluiwoi district, Kolaka regency - Southeast Sulawesi. Floribunda 4 (3): 75-80. [Indonesian]

Zhang QD, Jia RZ, Meng C, Ti CW, Wang TY. 2015. Diversity and population structure of a dominant deciduous tree based on morphological and genetic data. AoB Plants 7:1-13 DOI: 10.1093/aobpla/plv103. 